\title{
Preparation, Characterization and Biological Activity of New Nickel(II) Complexes Containing Mixed Ligands ${ }^{\star}$
}

\author{
Zuhoor F. Dawood*,Adeba Y. Shareef** \\ \& Manal A. Al-Shama ${ }^{* * *}$ \\ *Chemistry Department, Education College, Mosul University \\ **Biology Department, Science College, Mosul University \\ $* * *$ Chemistry Department, Science College, Mosul University
}

\section{الخلاصة}

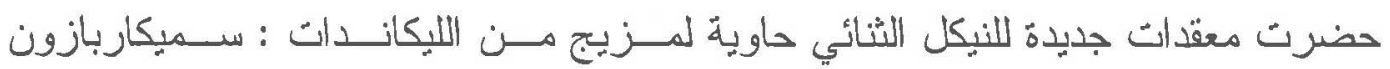

إنز الديهايد سميكاربازون(BCHCH)

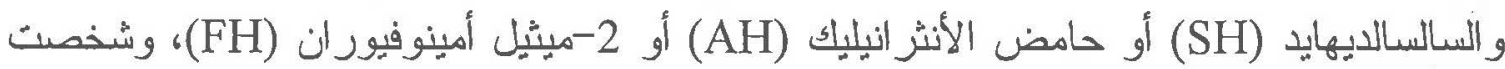

بطرق فيزيائية وكيميائية . أقترحت الصيغة أو BSCH = على خمسة جراثيم مرضية بأستخدام ثقنية الانتشار على سطح الاكار كمضادات للجر اثثيم ايجابية

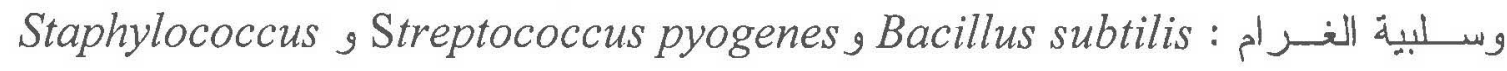
Pseudomonas aeruginosa و Proteus vulgaris gaureus

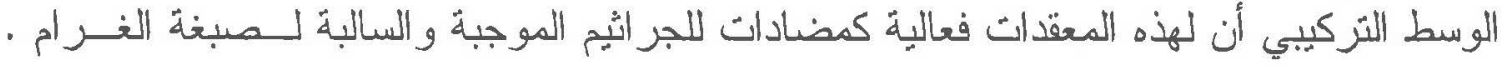

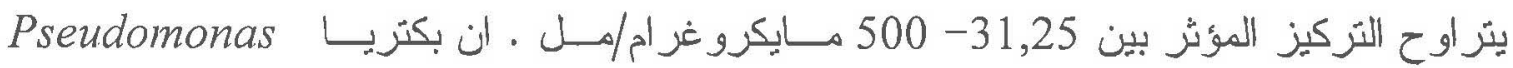

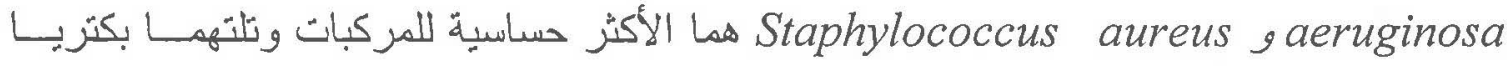

\section{ABSTRACT}

- Proteus vulgaris

Nickel(II) complexes containing mixed ligands; semicarbazone (SCH) \{benzaldehyde semicarbazone (BSCH) or 2-fluorobenzaldehyde semicarbazone $(\mathrm{FSCH})\}$ and salicylaldehyde $(\mathrm{SH})$ or anthranilic acid $(\mathrm{AH})$ or 2* methylaminofuran (FH) have been prepared and characterized physicochemically. Complexes of the type $\left[\mathrm{Ni}(\mathrm{SCH})(\mathrm{LH})_{2}\right]\left(\mathrm{NO}_{3}\right)_{2}$ \{ where $\mathrm{SCH}=$ $\mathrm{BSCH}$ or $\mathrm{FSCH}, \mathrm{LH}=\mathrm{SH}$ or $\mathrm{AH}$ or $\mathrm{FH}\}$ have been proposed. The biological activities of the resulted complexes have been evaluated by agar plate diffution technique against five human pathogenic bacterial strains: Bacillus subtilis, Streptococcus pyogenes, Staphylococcus aureus, Pseudomonas aeruginosa and Proteus vulgaris. The complexes were found

-Presented at the first conference on Biology, University of Mosul, college of Education , 4-5 September 2007 


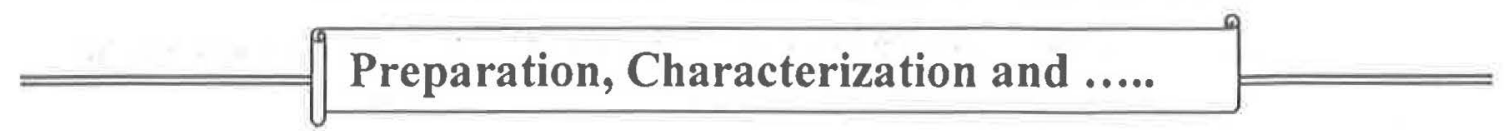

to have antimicrobial activity on some gram-positive and gram-negative bacteria, in vitro. The effective concentrations ranging between 31.25-500 $\mu \mathrm{g} / \mathrm{ml}$. Pseudomonas aeruginosa and Staphylococcus aureus were the most sensitive bacteria followed by Proteus vulgaris.

\section{INTRODUCTION}

Nickel complexes occurred in several nickel-containing enzymes and have been proposed to be involved in catalytic reaction. Nickel complexes with macrocyclic ligands have been prepared, and some of them are forming a coordination polymer [1-3] .

A good deal of work has been reported on the preparation and structural investigation of semicarbazone and their complexes [4-6]. This is due partially to their capability of acting as multidentate, NO, NNO, ONNO, donor with the formation of either mono- or bi- or poly-nuclear complexes $[7,8]$. In addition to their interesting ligational properties, semicarbazones and their complexes have important biological applications [9-10] .

There has been growing interest in the formation of mixed ligands chelates involving ligands containing different functional groups and transition metals of different oxidation states which can form chelates with ligands containing different donation sites [11]. On the other hand, coordination compounds with mixed ligands are of considerable importance in the field of metalloenzymes and other biological activities [12,13]. Hence a large body of the coordination chemistry of mixed ligands with transition and non-transition metal ions have been reported recently $[14,15]$. Due to the importance of mixed ligands complexes, we took a humble part in the chemistry of mixed ligands containing semicarbazones and their complexes, and some articles have been published on their coordination chemistry with transition and non-transi- tion metal ions [16-18] .

In view of this, and since mixed ligands complexes of semicarbazones and salicylaldehyde or anthranilic acid or 2-methylaminofuran with nickel (II) ion have not yet been reported, it is a matter of interest to determine the extent to which the biological properties of these ligands would be affected by incorporating nickel (II) ion.

In the present work, nickel (II) complexes with mixed ligands \{semicarbazones and salicylaldehyde or anthranilic acid or 2-methylaminofuran\} have been prepared and characterized physicochemically.

Also this work includes the study of antimicrobial activity of these complexes against Streptococcus pyogenes, Staphylococcus aureus, Bacillus subtilis, Pseudomonas aeruginosa and Proteus vulgaris. 


\section{$\int$\begin{tabular}{c}
$\begin{array}{c}\text { Zuhoor F. Dawood,Adeba Y. Shareef } \\
\text { \& Manal A. Al-Shama a }\end{array}$ \\
\hline \hline
\end{tabular} \\ EXPERIMENTAL}

\section{I- Chemicals :}

2-fluorobenzaldehyde, Nickel (II) nitrate, semicarbazide hydrochloride, 2methylaminofuran, anthranilic acid (Fluka) have been used as supplied, whereas benzaldehyde and salicylaldehyde (Fluka) have been used after purification by distillation.

\section{II- Preparation of the ligands :}

Semicarbazone ligands have been prepared according to standard methods [19]: 0.0890 mole of semicarbazide hydrochloride and 0.0163 mole sodium acetate dissolved in $10 \mathrm{ml}$ water have been mixed with 0.0940 mole of the appropriate aldehyde. The mixtures were shaken and heated on a water bath for few minutes then refluxed for one hour. On cooling, the solid products were separated, filtered off, washed with water, recrystallized from ethanol and dried. White crystals were obtained (m.p. of $\mathrm{BSCH}=200{ }^{\circ} \mathrm{C}$, $\mathrm{FSCH}=240^{\circ} \mathrm{C}$ ).

\section{III-Preparation of the complexes :}

The complexes have been prepared by the reaction of aqueous solution of nickel (II) nitrate with ethanolic solution of semicarbazones (BSCH or $\mathrm{FSCH}$ ) and salicylaldehyde or anthranilic acid or 2-methylaminofuran (SH, $\mathrm{AH}, \mathrm{FH}$ ) in 1:1:2 molar ratio at $\mathrm{pH}$ 6-7. The mixtures have been refluxed for 3 hrs., evaporated to about half their volumes and cooled. The resulting products were filtered, washed with diethylether and dried .

\section{IV-Analytical \& physical measurements}

The metal contents have been determined by a standard precipitation method [20].Relative molecular weights of the complexes have been determined cryoscopically [21]. Molar conductivities of the complexes have been measured in an electrolytic conductivity measuring set LF-42 using $10^{-3}$ $\mathrm{M}$ absolute ethanol $25^{\circ} \mathrm{C}$. Magnetic susceptibilities of the complexes have been measured by Bruker B.M6. IR spectra of the ligands and their complexes have been recorded on a Pye-Unicam 1100 spectrophotometer in the 400-4000 $\mathrm{cm}^{-1}$ range using $\mathrm{KBr}$ pellets. UV/Visible spectra have been recorded on Shimadzu-160 spectrophotometer for $10^{-3} \mathrm{M}$ solution of the ligands and their complexes in absolute ethanol at $25^{\circ} \mathrm{C}$ using a $1 \mathrm{~cm}$ cell.

\section{V- Antimicrobial assay of the complexes}

Five pathogenic microorganisms have been selected to study the antibacterial activity of the complexes in this research. These were gram positive \{Streptococcus pyogenes, Staphylococcus aureus, Bacillus subtilis $\}$ and gram negative \{Pseudomonas aeruginosa and Proteus vulgaris\}. All the bacterial strains have been isolated from clinical samples (skin infection) and 
identified before use in Biology Department, Science College, Mosul University. The antibacterial activity of the compounds has been evaluated by agar plate diffusion technique [22,23] against a variety of medicinally important gram-positive and gram-negative bacteria. In this method nutrient agar plates have been seeded with $0.1 \mathrm{ml}$. of the broth culture of the tested microorganism containing $\left(10^{8}\right)$ cells $/ \mathrm{ml}$, filter paper discs were impregnated with the tested materials then placed on the surface of seeded nutrient agar plates, the plates were incubated at $37^{\circ} \mathrm{C}$ for $24 \mathrm{hrs}$. The zone of inhibition have been measured using a special calibrated lences.

\section{VI-Determination of minimum inhibitory concentration (MIC):}

Different concentrations of the tested materials in dimethylsulphoxide solutions $(7.600,15.375,31.250,62.500,125,250,500 \mu \mathrm{g} / \mathrm{ml})$ were used for the determination of minimum inhibitory concentration (MIC) $[22,23]$. The lowest dilution which inhibits the growth have been recorded, each experiment were carried out in triplicates for each concentration of the complexes as well as for the microorganisms alone as positive controls for the growth.

\section{RESULTS AND DISCUSSION}

The reaction of nickel (II) nitrate with the semicarbazone and Salicylaldehyde or anthranilic acid or 2-methylaminofuran ligands (The structures of the ligands are shown in Figure 1) in 1:1:2 molar ratio may be represented by the following reactions :

$\mathrm{Ni}\left(\mathrm{NO}_{3}\right)_{2} \cdot 6 \mathrm{H}_{2} \mathrm{O}+\mathrm{SCH}+2 \mathrm{LH} \longrightarrow \quad\left[\mathrm{Ni}(\mathrm{SCH})(\mathrm{LH})_{2}\right]\left(\mathrm{NO}_{3}\right)_{2}+6 \mathrm{H}_{2} \mathrm{O}$ (where $\mathrm{SCH}=\mathrm{BSCH}$ or $\mathrm{FSCH} ; \mathrm{LH}=\mathrm{SH}$ or $\mathrm{AH}$ or $\mathrm{FH}$ )

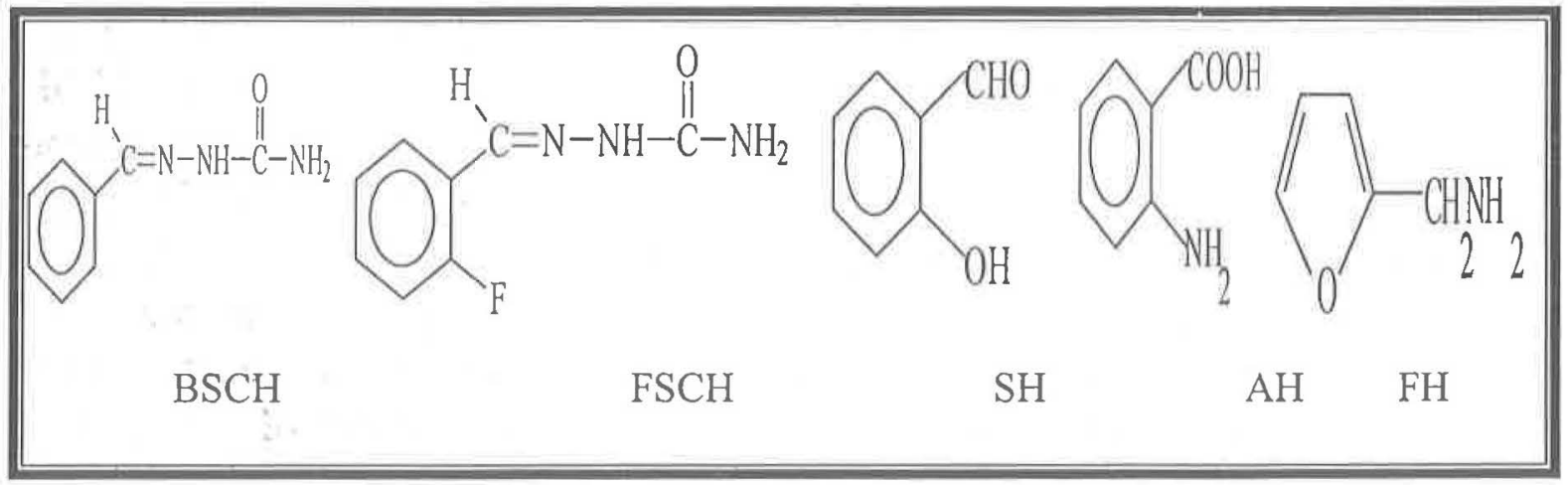

Figure (1) : Structures of the ligands

The resulted complexes are colored solid, moderately soluble in ethanol, soluble in dimethylformamide and dimethylsulfoxide. The elemental analyses reveal that the complexes have the composition $\left[\mathrm{Ni}(\mathrm{SCH})(\mathrm{LH})_{2}\right]\left(\mathrm{NO}_{3}\right)_{2}$. The molar conductivities of the complexes in $10^{-3} \mathrm{M}$ absolute ethanol are determined, the values shown in Table- 1 approach those expected for 1:2 electrolytes [24]. The magnetic moments of the complexes calculated from the corrected magnetic susceptibilities 
determined at room temperature are shown in Table-1. The $\mu_{\text {eff }}$ values reported for the complexes (2.63-2.71 B.M.) supported the monomeric structures indicating octahedral geometry around the metal ions [17].

Table (1) : Analytical data and physical properties of the complexes

\begin{tabular}{|c|c|c|c|c|c|c|c|}
\hline No & Compounds & Colors & $\underset{{ }^{0} \mathrm{C}}{\text { M.P. }}$ & $\stackrel{*}{*}$ & $\begin{array}{l}* * \\
\mu_{\mathrm{eff}}\end{array}$ & $\begin{array}{c}\text { M.Wt } \\
\text { (Calc./Obs.) }\end{array}$ & $\begin{array}{c}\% \mathrm{Ni} \\
\text { (Calc./Obs.) }\end{array}$ \\
\hline 1 & {$\left[\mathrm{Ni}(\mathrm{BSCH})(\mathrm{SH})_{2}\right]\left(\mathrm{NO}_{3}\right)_{2}$} & Black & $217-219$ & 82.8 & 2.710 & $\begin{array}{l}557.70 \\
566.98 \\
\end{array}$ & $\begin{array}{c}10.52 \\
9.77\end{array}$ \\
\hline 2 & {$\left[\mathrm{Ni}(\mathrm{BSCH})(\mathrm{AH})_{2}\right]\left(\mathrm{NO}_{3}\right)_{2}$} & Green & $193 d$ & 89.3 & 2.630 & $\begin{array}{l}619.70 \\
629.29\end{array}$ & $\begin{array}{l}9.47 \\
9.08\end{array}$ \\
\hline 3 & {$\left[\mathrm{Ni}(\mathrm{BSCH})(\mathrm{FH})_{2}\right]\left(\mathrm{NO}_{3}\right)_{2}$} & Green & $205-206 d$ & 83.6 & 2.645 & $\begin{array}{l}539.70 \\
549.25\end{array}$ & $\begin{array}{l}10.88 \\
10.50\end{array}$ \\
\hline 4 & {$\left[\mathrm{Ni}(\mathrm{FSCH})(\mathrm{SH})_{2}\right]\left(\mathrm{NO}_{3}\right)_{2}$} & $\begin{array}{l}\text { Dark } \\
\text { green }\end{array}$ & $176-178$ & 82.5 & 2.700 & $\begin{array}{l}575.70 \\
584.85\end{array}$ & $\begin{array}{l}10.20 \\
9.33\end{array}$ \\
\hline 5 & {$\left[\mathrm{Ni}(\mathrm{FSCH})(\mathrm{AH})_{2}\right]\left(\mathrm{NO}_{3}\right)_{2}$} & $\begin{array}{l}\text { Pale } \\
\text { green }\end{array}$ & $137-138$ & 78.2 & 2.670 & $\begin{array}{l}637.70 \\
647.39\end{array}$ & $\begin{array}{l}9.20 \\
8.92\end{array}$ \\
\hline 6 & $\left.\mathrm{Ni}(\mathrm{FSCH})(\mathrm{FH})_{2}\right]\left(\mathrm{NO}_{3}\right)_{2}$ & $\begin{array}{l}\text { Dark } \\
\text { brown }\end{array}$ & $102-103$ & 70.9 & 2.690 & $\begin{array}{l}557.70 \\
567.73\end{array}$ & $\begin{array}{l}10.53 \\
10.20\end{array}$ \\
\hline
\end{tabular}

${ }^{* \wedge} \mathrm{M}=$ molar conductivities in $\Omega^{-1} \mathrm{~cm}^{2} \mathrm{~mol}^{-1} ;{ }^{* *}$ values in Bohr magneton (B. M.)

The infrared spectra of semicarbazone ligands showed a strong band at about $1675 \mathrm{~cm}^{-1}$ which was attributed to the $\mathrm{C}=\mathrm{O}$ group [7]. This value shifted towards a lower frequency on coordination indicating the formation of a chelation between the oxygen of the carbonyl group and the metal ion [7]. The next strong band at $1580 \mathrm{~cm}^{-1}$ which was attributed to $\mathrm{C}=\mathrm{N}$ group shifted towards a lower frequency on coordination $[7,8]$ due to the decrease of the bond order as a result of metal nitrogen bond formation $[7,8]$. The position of the ligand in the range $3300-3500 \mathrm{~cm}^{-1}$ remained unaltered in the complexes indicating that there is no coordination through the $\mathrm{NH}$ group $[7,8]$. The infrared spectra of salicylaldehyde showed bands at 1700, 3150$3250,1250 \mathrm{~cm}^{-1}$ which were due to $v_{\mathrm{C}=\mathrm{O}}, v_{\mathrm{OH}}, v_{\mathrm{C}-\mathrm{O}}$, respectively, upon complexation these bands were shifted (Table 2). The shift in these vibrations indicated their coordination with $C \cdots 0 \cdots C$ the metal ion [30]. The positive shift in the stretching frequency upon complexation indicated that there was a $\mathrm{Cu}-\mathrm{O}$ bond. Such increase in frequency $\mathrm{C}=0 \cdots \mathrm{C}$ may be related to an increase in the dipolar contribution of [30]. The infrared spectra of anthranilic acid showed a wide bands in the region 3500 3600 and $3400 \mathrm{~cm}^{-1}$ due to the stretching vibration of carboxylic $\mathrm{OH}$ and $\mathrm{NH}_{2}$ groups, respectively, this wide range was due to the hydrogen bonding. In the spectra of the complexes, it is more difficult to observe the coordination due to the presence of different groups and hydrogen bonding. Whatever this wide band was shifted to lower frequency [25]. The other two bands observed at $1350-1430 \mathrm{~cm}^{-1}$ and $1550-1600 \mathrm{~cm}^{-1}$ were due to the symmetric and asymmetric stretching frequencies of carboxylic group, respectively. On complexation these bands were shifted to $1350-1420 \mathrm{~cm}^{-1}$ 


\section{Preparation, Characterization and ......}

and 1500-1575 $\mathrm{cm}^{-1}$, respectively [26]. The difference between the symmetry and asymmetry stretching vibration of $\mathrm{COO}^{-}$group $(\Delta v$ which was equal to 150-155 $\mathrm{cm}^{-1}$ ) gave indication about the manner of coordination of carboxylic group, this value showed that the anthranilic acid coordinated through $\mathrm{COO}^{-}$group which was acted as monodentate [26]. On the other hand, the spectra of all the complexes showed new bands at $1380-1385 \mathrm{~cm}^{-1}$ as due to ionic nature of nitrate group $[17,26]$. In addition, new bands were observed in the spectra of the complexes at 480-500 and 580-590 $\mathrm{cm}^{-1}$ as due to $v_{\mathrm{Ni}-\mathrm{N}}$ and $v_{\mathrm{Ni}-\mathrm{O}}$, respectively. The presence of these bands (Table 2) supported the coordination of the ligands to the metal ion.

Table (2): IR spectral data of the ligands and their complexes (values in $\mathrm{cm}^{-1}$ )

\begin{tabular}{|c|c|c|c|c|c|c|c|c|c|c|}
\hline Comp. & $v \mathrm{C}=\mathrm{N}$ & UNH & $v C=0$ & $\begin{array}{c}\text { UC-O } \\
\text { Ph }\end{array}$ & $\begin{array}{c}\mathrm{UCOO}^{-} \\
\text {(s) }\end{array}$ & $\begin{array}{l}\mathrm{UCOO}^{-} \\
\text {(as) }\end{array}$ & $\boldsymbol{v} C=\mathrm{O}=\mathrm{C}$ & $\begin{array}{c}v C=0 \\
\text { ald. }\end{array}$ & UNi-O & UNi-N \\
\hline BSCH\&SH & 1580 & $3200-3500$ & 1675 & 1250 & - & - & - & 1710 & - & - \\
\hline 1 & 1560 & $3200-3500$ & 1650 & 1300 & - & - & . & 1690 & 550 & 600 \\
\hline BSCH\&AH & 1580 & $3200-3500$ & 1675 & - & 1350 & 1550 & - & - & - & - \\
\hline 2 & 1560 & $3200-3500$ & 1645 & - & 1350 & 1500 & - & - & 540 & 600 \\
\hline $\mathrm{BSCH} \& \mathrm{FH}$ & 1580 & $3200-3500$ & 1675 & - & & & 1490 & - & - & . \\
\hline 3 & 1550 & $3200-3500$ & 1650 & - & - & - & 1525 & - & 560 & 610 \\
\hline FSCH\&SH & 1580 & $3200-3500$ & 1675 & 1250 & - & - & - & 1710 & - & - \\
\hline 4 & 1550 & $3200-3500$ & 1650 & 1320 & - & - & - & 1690 & 540 & 610 \\
\hline FSCH\&AH & 1580 & $3200-3500$ & 1675 & $\cdot$ & 1420 & 1620 & - & - & - & - \\
\hline 5 & 1555 & $3200-3500$ & 1650 & - & 1420 & 1575 & - & 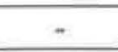 & 540 & 600 \\
\hline FSCH\&FH & 1580 & $3200-3500$ & 1675 & - & - & - & 1495 & - & - & - \\
\hline 6 & 1560 & $3200-3500$ & 1640 & - & - & & 1520 & - & 550 & 650 \\
\hline
\end{tabular}

The electronic spectra of the Ni (II) complexes (Table 3) showed absorption bands at 9035-10846 $\mathrm{cm}^{-1}, 16666-20000 \mathrm{~cm}^{-1}$ and $21570-24570$ $\mathrm{cm}^{-1}$ due to $v_{1}, v_{2}$ and $v_{3}$, respectively, (attributed to ${ }^{3} \mathrm{~A}_{2} \mathrm{~g}(\mathrm{~F}) \rightarrow{ }^{3} \mathrm{~T}_{2} \mathrm{~g}(\mathrm{~F})$, ${ }^{3} \mathrm{~A}_{2} \mathrm{~g}(\mathrm{~F}) \rightarrow{ }^{3} \mathrm{~T}_{1} \mathrm{~g}(\mathrm{~F})$ and ${ }^{3} \mathrm{~A}_{2} \mathrm{~g}(\mathrm{~F}) \rightarrow{ }^{3} \mathrm{~T}_{1} \mathrm{~g}(\mathrm{P})$ transitions) which were expected for $\mathrm{d}^{8}$ system having high spin octahedral geometries [27]. The ligand field parameter B and the ligand field splitting energy (10Dq) have been calculated (27). The values of â of the complexes were between 0.70 0.78 indicating the covalent character of the bond concerned. However, the electronic spectral data suggested octahedral geometries of all the complexes (Figure 2)[27]. 

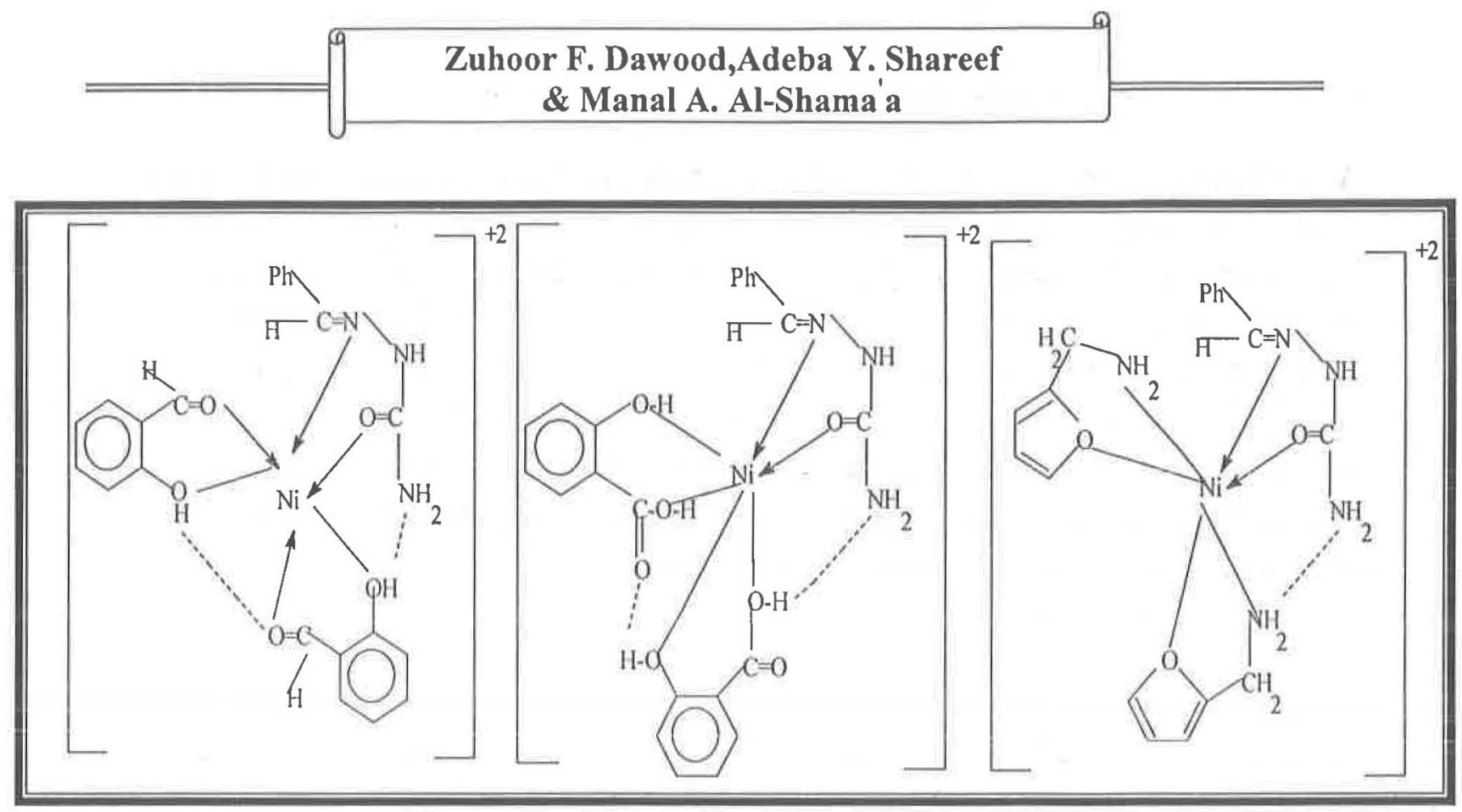

Figure (2) : Proposed structures of the complexes

Table (3) : Electronic spectral data of the complexes

\begin{tabular}{||c|c|c|c|c|c|c|c|c|c||}
\hline Comp. & $\begin{array}{c}\mathbf{U}_{1^{*}} \\
\mathbf{c m}^{-1}\end{array}$ & $\begin{array}{c}\mathbf{U}_{2} \\
\mathbf{c m}^{-1}\end{array}$ & $\begin{array}{c}\mathbf{U}_{3} \\
\mathbf{c m}^{-1}\end{array}$ & $\begin{array}{c}\mathbf{C} \cdot \mathbf{T} \\
\mathbf{c m}^{-1}\end{array}$ & $\begin{array}{c}\text { B } \\
\mathbf{c m}^{-1}\end{array}$ & $\mathbf{1 0 D q}$ & $\beta$ & Dq/B & C.F.S.E \\
\hline 1 & 9035 & 16666 & 21570 & 26520 & 722 & 9035 & 0.70 & 1.25 & 10845 \\
\hline 2 & 10845 & 20000 & 24568 & 28480 & 802 & 10845 & 0.78 & 1.35 & 13015 \\
\hline 3 & 9037 & 16667 & 21575 & 28160 & 722 & 9037 & 0.70 & 1.25 & 10845 \\
\hline 4 & 9038 & 16666 & 21576 & 27700 & 722 & 9038 & 0.70 & 1.25 & 10845 \\
\hline 5 & 10845 & 20000 & 24568 & 26300 & 802 & 10845 & 0.78 & 1.35 & 13015 \\
\hline 6 & 10846 & 20000 & 24570 & 28500 & 802 & 10846 & 0.78 & 1.35 & 13015 \\
\hline \hline
\end{tabular}

* calculated

Many chemical compounds had a good ability to attack the bacteria through their effects on the synthesis of ribonucleic acid which could be resulted from the inhibition action of these compounds on the DNA of the bacteria which caused inhibition of the activities of DNA enzyme including the separation of supercoiling or decantenation or unknotting of the DNA $[28,29]$. Moreover, the antibacterial agents were known to attack the cell in a variety of ways such as: killing or inhibiting the growth of micro- organisms by affecting special target sites like the synthesis of cell wall, protein and nucleic acid,or by inhibiting the function of the cell membrane, binding of the sulfhydryl groups of the cell enzymes with the complexes (30-32). Numerous experiments have been done to determine the antimicrobial influence of the complexes. Table 4 showed that the complexes numbers 1 and 2 have anti- microbial activity against Staphylococcus aureus, Pseudomonas aeruginosa and Proteus vulgaris, whereas complex 4 have antimicrobial activity against Bacillus subtilis, Staphylococcus aureus and 


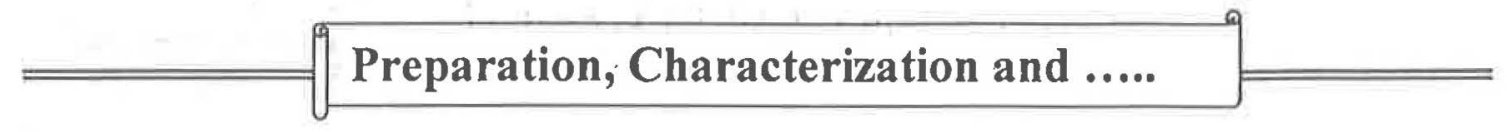

Pseudomonas aeruginosa. Complex 3 have only antimicrobial activity against Staphylococcus aureus and Pseudomonas aeruginosa, meanwhile complex 5 have antimicrobial activity against Streptococcus pyogenes and Pseudomonas aeruginosa. As heavy metal ions preferentially bind to $\mathrm{SH}$ group of the cell enzyme more strongly, it is logical to assume that the complexes screened were involved in a competitive equilibria involving the $\mathrm{SH}$ group of the cell enzyme. Therefore, we concluded that most of the complexes aquire a good biological activity (Figure 3). If this is the case, the complexes which were expected to bind to $\mathrm{SH}$ group of the cell enzymes acted more strongly than the nitrogen donor atom in the ligands (33) and should have lower MIC (Table 5) than complexes (Table 4) consequently, these observations have been consistent with that observed by many workers (33).

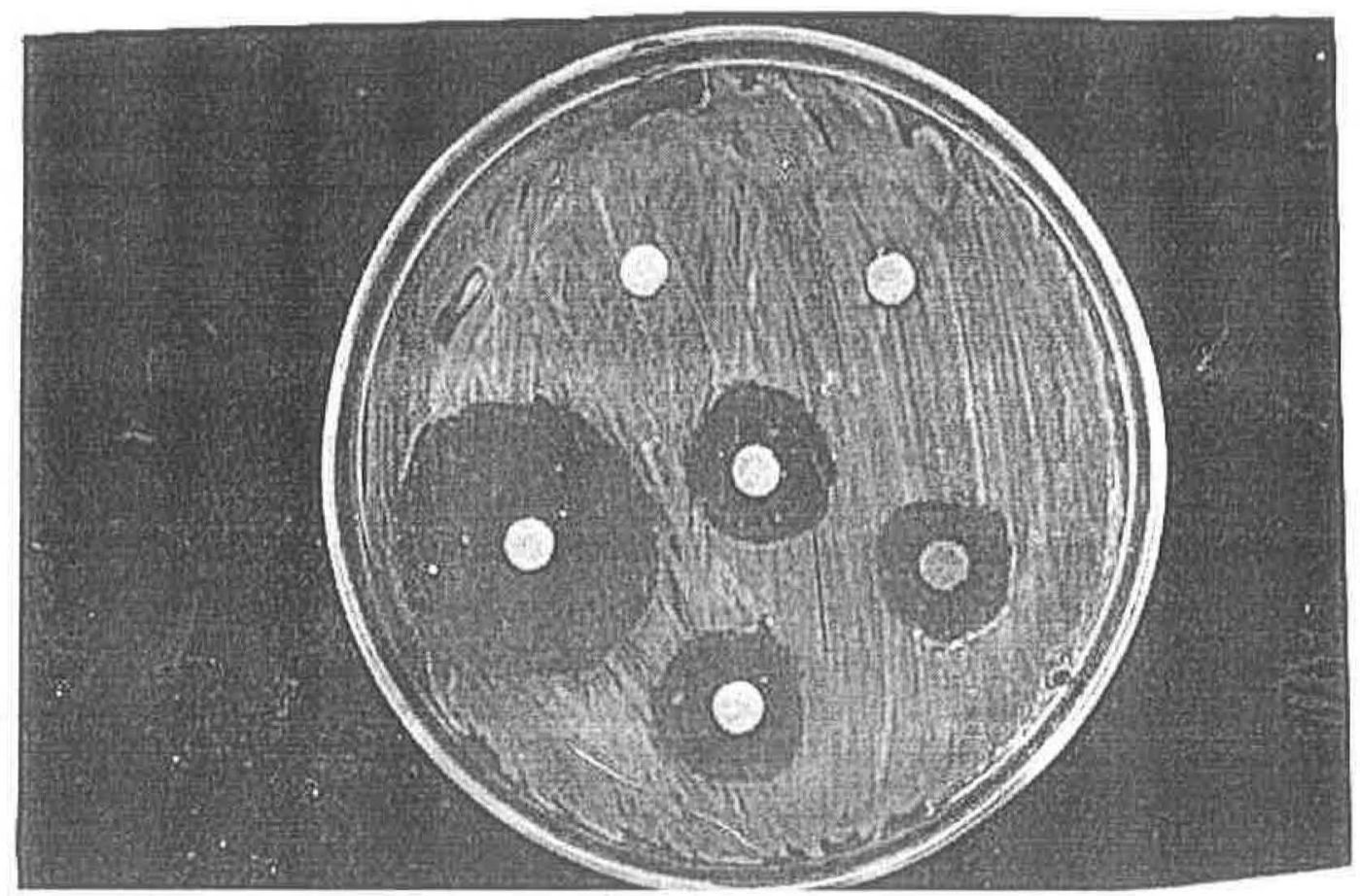

Figure (3) : Antimicrobial activity of different concentrations of complex 1 on Proteus vulgaris

Table (4) : Antibacterial activity of the complexes

\begin{tabular}{||c|c|c|c|c|c||}
\hline No. & $\begin{array}{c}\text { Bacillus } \\
\text { subtilis }\end{array}$ & $\begin{array}{c}\text { Streptococcus } \\
\text { pyogenes }\end{array}$ & $\begin{array}{c}\text { Staphylococcus } \\
\text { aureus }\end{array}$ & $\begin{array}{c}\text { Proteus } \\
\text { volcarus }\end{array}$ & $\begin{array}{c}\text { Pseudomonas } \\
\text { aeruginosa }\end{array}$ \\
\hline 1 & $\mathrm{R}$ & $\mathrm{R}$ & $\mathrm{MS}$ & $\mathrm{S}$ & $\mathrm{S}$ \\
\hline 2 & $\mathrm{R}$ & $\mathrm{R}$ & $\mathrm{S}$ & $\mathrm{S}$ & $\mathrm{S}$ \\
\hline 3 & $\mathrm{R}$ & $\mathrm{R}$ & $\mathrm{S}$ & $\mathrm{R}$ & $\mathrm{S}$ \\
\hline 4 & $\mathrm{MS}$ & $\mathrm{R}$ & $\mathrm{MS}$ & $\mathrm{R}$ & $\mathrm{MS}$ \\
\hline 5 & $\mathrm{R}$ & $\mathrm{MS}$ & $\mathrm{R}$ & $\mathrm{R}$ & $\mathrm{S}$ \\
\hline 6 & $\mathrm{R}$ & $\mathrm{R}$ & $\mathrm{R}$ & $\mathrm{R}$ & $\mathrm{R}$ \\
\hline
\end{tabular}

$\mathrm{S}=$ Sensitive; zone diameter not more than $6 \mathrm{~mm}$ less than control[34,35]

$\mathrm{MS}=$ Intermediate; Moderately sensitive zone diameter of 6-12 $\mathrm{mm}$ less than control

$\mathrm{R}=$ Resistant; zone diameter of $12 \mathrm{~mm}$ or less than control . 


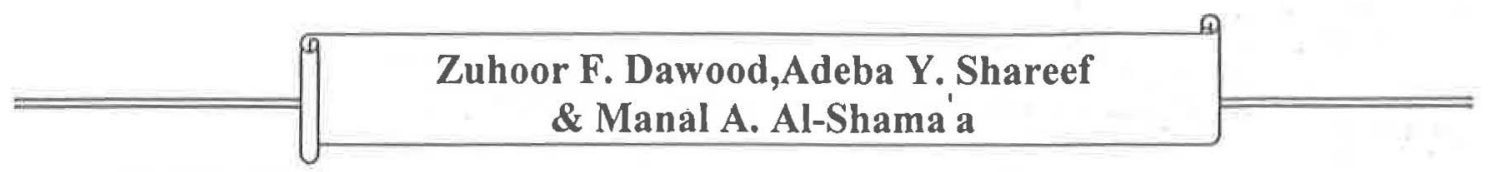

Table (5) : Minimum inhibitory concentrations $(\mu \mathrm{g} / \mathrm{ml})$ of the complexes

\begin{tabular}{||c|c|c|c|c|c||}
\hline No. & $\begin{array}{c}\text { Bacillus } \\
\text { subtilis }\end{array}$ & $\begin{array}{c}\text { Streptococcus } \\
\text { pyogenes }\end{array}$ & $\begin{array}{c}\text { Staphylococcus } \\
\text { aureus }\end{array}$ & $\begin{array}{c}\text { Proteus } \\
\text { volcarus }\end{array}$ & $\begin{array}{c}\text { Pseudomonas } \\
\text { aeruginosa }\end{array}$ \\
\hline 1 & - & - & 500 & 125 & 125 \\
\hline 2 & - & - & 62.50 & 31.25 & 62.50 \\
\hline 3 & - & - & 62.50 & - & 31.25 \\
\hline 4 & 500 & - & 500 & - & 500 \\
\hline 5 & - & 500 & - & - & 62.50 \\
\hline 6 & - & - & - & - & - \\
\hline
\end{tabular}

means that there is no activity appeared of these compounds this can be observed in Table(1)

\section{CONCLUSION}

This work in fact is a continuation of our studies including mixed ligand complexes. In this work some observations have been achieved that lead to establish the following points:

1- Semicarbazones acted as bidentate chelating ligands joint to nickel (II) ion through the carbonyl-oxygen and azomethane-nitrogen atoms. Salicylaldehyde, anthranilic acid and 2-methylaminofuran acted as bidentate chelating ligands

2- Nitrate ion joint in an ionic manner to the metal ion .

3- Nickel (II) ion is probably hexacoordinated, leading to high spin octahedral geometry.

4- Complexes 1, 2, 3, 4 and 5 showed good antimicrobial activities against Peseudomonas aeruginosa.

5-Complexes 1,2,3 and 4 showed good antimicrobial activities against Staphylococcus aureus .

6- Complexes 1 and 2 showed good antimicrobial activities against Proteus vulgaris .

7- Complex 4 showed good antimicrobial activity against Bacillus subtilis while Complex 5 showed good antimicrobial activity against Streptococcus pyogenes.

8- Complex 6 had no antimicrobial activity against the five microorganism. 


\section{REFERENCES}

1. Eichhorn G., and Marzilli L., Advances in Inorganic Biochemistry; Elsevier Sci. Pub. Company, Inc., New York, (1982).

2. Tyaga Rajo V.J., Ranbaore V., Atre V., and Ganorkar M.C., J. Indian Chem. Soc., LIX: 199 (1982).

3. Jouadel M., Thanh X.D., Bonet G., Bonneau S. and Khan M.A., Anticancer Res., 22, 1713 (2002).

4. Yin D.D., Wang Z.W. and Shan L., Chinese J. Chem., 18: 364 (2000) .

5. Gupta P., Basali F., Peng S.M., Lee G.H. and Bhattacharya S., Inorg. Chem., 42: 2069 (2003).

6. De Sousa G.F., Valdés-Martinez J., Pérez G.E., Toscano R.A., Abras, and Filgueiras C.A.L., J. Brazilian Chem. Soc., 13: 559 (2002) .

7. Kumar Y. and Tolani S. P., Croat. Chem. Acta, 62: 73 (1989).

8. Kanoongo N., Singh R.V. and Tondon J.P., Synth. React. Inorg. Met.Org. Chem., 17: 837 (1987) .

9. Reddy H.K., Reddy S.P. and Ravindra B.P., Transit. Met. Chem., 25: 154 (2000) .

10. Hurta F., Valko L., Valko M., Sigma J. and Košturiak A., Acta Phys. Slovaca, 51: 281 (2001).

11. Afrasiabi Z., Sinn E., Fok J., Mehta K., Rath N., Deobagakar D., Anson Ch. A. and Powell A.K., Inorg. Chem., 44: 1154 ( 2005).

12. Hussain R.K., Sambasiva R.P. and Ravindra B.P., Transit. Met. Chem., 25: 505 (2000).

13. Ramesh R. and Sivamasundari M., Synth. React. Inorg. Met-Org. Chem., 33: 899 (2003).

14. Hassan F.S.M., Arabian J. Sci. \& Eng., 30, 29 (2005)

15. Yao Y., Cai Q., Kou H., Li H., Wang D., Yu R., Chen Y. and Xing X., Chem. Soc. Japan, 33: 1270 (2004).

16. Dawood Z.F., Sci. \& Tech., 17, 35 (2002).

17. Dawood Z.F., Hussein S.H. and Al-Shamaa M.A., Sci. \& Tech., 21: 71 (2004).

18. Dawood Z.F. and Ritha A.Y., R. J. of Aleppo., 54, 2007

19. Vogel A.I., Textbook of Practical Organic Chemistry; Longmans Green , London, $3^{\text {th }}$ ed., 344 (1964).

20. Vogel A.I., Textbook of Quantitative Inorganic Analysis; Longmans, $4^{\text {th }}$ ed., 447 (1981) .

21. Danials J.W., Experimental Physical Chemistry, McGraw-Hill, $6^{\text {th }}$ ed., $1184(1962)$

22. Collins C.H., Lyne P.M. and Grange J.M., Microbiological Methods; Butterworths, London, $6^{\text {th }}$. ed. (1989).

23. Dutta M.M., Goswami B.N. and Kataky J.S., J. Heterocyclic Chem., 23: 793 (1986).

24. Geary W.J., Coord. Chem. Rev., 7: 81 (1971). 
25. Das G., Shukla R., Mandal S., Singh R. and Bharadwaj P.K., Inorg. Chem., 36: 323 (1997).

26. Nakamoto K., Infrared and Raman Spectra of Inorganic and Coordination Compound; Part B , John Wiley and sons , Inc. , $5^{\text {th }}$. ed., 23 (1997).

27. Lever A.B.P., J. Chem. Edu., 45: 711 (1968).

28. Katzung B.G., Chemotherapeutic Drugs in Basic and Clinical Pharmacology, Hall International Inc., $4^{\text {th }}$ ed., 545 (1989).

29. Piddock L.J.V., Walters R.N. and Diver J.M., Antimicrob. Agents \& Chemother., 34: 2331 (1990).

30. Goodman L.S. and Gilman A., The Pharmacological Basis of Therapeutics; MacMilon, New York ; 1038 (1965).

31. Casas J.S., Castineiras A. and Arguelles M.C.R., J. Inorg. Biochem., 76: 277 (1999).

32. Dawood Z.F., Shareef A.Y. and Ahmad N.G., R. J. of Aleppo, 54 (2007). 33. Nadira W. and Singh H.B., Inorg. Chim. Acta, 151: 387 (1988).

34. Garrod L.P., Lambert H.P. and Grady F.O., Antibiotic and Chemotherapy; Churchill Livingstone, New York, $5^{\text {th }}$ ed. , 459 (1981).

35. Vandepitte J., Engback K., Piot and Heuk C., "Basic Laboratory Procedures in Clinical Bacteriology" ; World Healt Organisation, Geneva, 84 (1991). 